This item was submitted to Loughborough's Research Repository by the author.

Items in Figshare are protected by copyright, with all rights reserved, unless otherwise indicated.

\title{
The contribution of Real Madrid's first five European Cups to the emergence of a common football space
}

PLEASE CITE THE PUBLISHED VERSION

PUBLISHER

(C) Palgrave Macmillan

\section{VERSION}

AM (Accepted Manuscript)

\section{PUBLISHER STATEMENT}

This work is made available according to the conditions of the Creative Commons Attribution-NonCommercialNoDerivatives 4.0 International (CC BY-NC-ND 4.0) licence. Full details of this licence are available at: https://creativecommons.org/licenses/by-nc-nd/4.0/

\section{LICENCE}

CC BY-NC-ND 4.0

\section{REPOSITORY RECORD}

Garcia, Borja, Ramon Llopis-Goig, and Agustin Martin. 2019. "The Contribution of Real Madrid's First Five European Cups to the Emergence of a Common Football Space". figshare. https://hdl.handle.net/2134/16139. 
Borja García-García

Ramón Llopis-Goig

Agustín Martín

The contribution of Real Madrid's first five European Cups to the emergence of a common football space

\section{Introduction}

Real Madrid won the first five editions of the European Champion Clubs’ Cup (now formally known as the UEFA Champions League, and to which we will refer hereon as the European Cup) between 1956 and 1960, contributing decisively to the competition’s consolidation. The tournament's history started towards the end of 1954, when a journalist of the French sports daily L'Équipe, Gabriel Hanot, published an article arguing the need to organise a competition that could bring together the champions of every European league. However, this was not an original proposal. Thirty years before Hanot's article proposals for such a football competition were circulated among the game’s ruling elite. Unfortunately, at that time the lack of a good transport infrastructure to travel through Europe discouraged the proposers which, instead, turned their attention to regional supranational competitions, such as the Mitropa Cup or the Latin Cup.

The first five editions of the European Cup witnessed as many victories of Real Madrid, thus forging an indissoluble bond between the competition and the Spanish club. These five European titles did not only cement the supremacy of Real Madrid on the pitch as a great football team, but they also contributed to the consolidation of the European Cup itself in the public's imaginary. We also argue that given the expectations raised by Real Madrid's triumphs across Europe those matches might have contributed as well to the emergence of a European football space. Since 1955 
Real Madrid occupied an ever increasing space in the press across Europe. Real Madrid was then considered as the best expression of modernity in football.

This chapter aims to analyse the meaning of these five European Cup titles for the emergence and definition of a nascent European football space. We, of course, also question whether such a common space can be found. The chapter explores in depth the reasons behind Real Madrid's enthusiasm with the new European competition. We also examine the social impact that Real Madrid's hegemony in the European Cup had in the context of Spain's international isolation during General Franco’s dictatorship (1939-1975).

In order to achieve the above mentioned objectives, the chapter relies on thematic analysis of selected publications in the Spanish and British press during those years. Moreover, we have also relied on a review of academic literature on the role of Real Madrid during the Franco dictatorship years, mainly the 1950s and 60s. This chapter is part of wider on-going research. In this research we examine the content of two Spanish dailies ( $A B C$ and Marca) and three British newspapers (The Guardian, The Times and the Daily Mirror). We searched these newspapers for content related to Real Madrid on specific dates: The semifinal games (two legs) and the final of each one of the five years where Real Madrid won the European Cup. We searched for content the day of each match, the day before and two days after each one of the matches. This chapter is a presentation of the findings obtained through thematic analysis of the data obtained through those searches.

\section{The context of the creation of the European Cup}

In today's context of extreme difficulties for the European integration project, it is striking to observe the determination and vision of those who designed the European Cup just a few years after the end of World War II. It was a fragmented continent, divided between winners and losers, democracies and dictatorships, east and west. It was, moreover, a very weak public space, if at all, 
where only some tenuous links through mass media (European Broadcasting Union) or transport (development of commercial aviation) could be recognised.

The origin of the European Cup tends to be credited to Gabriel Hanot, an editor at the French sports daily L'Équipe. Hanot reacted to the headline 'World Champions' that the London press used to report on Wolverhampton Wonderers’ (Wolves) victory over Honved Budapest in a friendly match. Wolves' victory over their Hungarian rivals in the autumn of 1954 came against a backdrop of perceived decline of English football. Hence the triumphalist headlines of the local press. Wolves, current English League champions in 1954, defeated Spartak Moscow (4-0) and Honved (3-2) in both friendly matches. That Honved team (whose skipper was Ferenc Puskas), fed most of the players to the Hungarian national team that dominated European football during the 1950s. Thus, victories over such potent rivals were greeted by the Daily Mail and other newspapers with celebratory headlines that considered Wolves to be 'World Champions' as they had beaten the best teams in the continent (Relaño, 2005, p. 20; Ball, 2012, p. 120).

Gabriel Hanot, having read the euphoric press reports, pointed out the need to create an official competition among Europe’s best clubs. Building on Hanot's idea, Jacques Goddet argued the need to promote 'a world championship, or at least European championship, for clubs that is wider and more inclusive than the Central European Cup and more original than the European Championships for national teams' (L’Équipe, 15 December 1954). Just a day later, the same French newspaper published an article authored by Jacques de Ryswick where he presented his idea of a 'European clubs' championship', with the participation of 12 or 14 clubs that would play two-leg ties on weekdays in the evening (Bahamonde, 2002; González Calleja, 2010).

L'Équipe decided to disseminate and promote their idea among the most important football clubs and sport newspapers in the continent. The idea was favourably received in Spain, where Real Madrid was enthusiastically supportive. It is curious to note that L'Équipe had also invited FC Barcelona to be part of their project. This was due to the fact that the L'Equipe and France Football had two correspondents in Spain, one in Madrid and one in Barcelona. It was the newspaper's 
Barcelona correspondent, Carlos Pardo, who met with FC Barcelona officials. However, the club’s secretary (a position akin to today’s Chief Executive Officer) considered such a project unrealistic because he would favour a rebirth of a Catalan championship, a tournament that was played for a few years before the Spanish Civil War. The reaction of Real Madrid to L'Équipe's proposal was quite opposite to FC Barcelona’s. As Carlos Pardo himself explained in an interview to the Barcelona-based La Vanguardia in 2004, Real Madrid’s secretary, Raimundo Saporta, was extremely positive about the idea. Indeed, Saporta, speaking on the phone, asked Pardo to fly to Madrid immediately to meet Real Madrid’s chairman, Santiago Bernabéu, the club’s treasurer and himself (Luque and Luna, 2004, 63).

It was at the beginning of 1955 when L'Équipe finally decided to go ahead and organise the tournament. Jacques Ferran, one of the editors, was in charge of drafting the competition regulations, which were then sent to the participating clubs for their consideration. Initially the proposal met with the scepticism of both the Union of European Football Associations (UEFA) and the International Federation of Football Associations (FIFA). In other words: the governing bodies of football at global and European level both hesitated to support the competition, giving some mixed responses, perhaps in the hope that the idea would fade away. However, both L'Équipe and the clubs involved pressed ahead despite the governing bodies’ initial negative reaction. Having seen the impetus of the emerging idea, FIFA proposed some alternative international club competitions, such as the rebirth of the Mitropa Cup - suspended since 1939 - and a new tournament, the Inter-Cities Fairs Cup (the predecessor of the current UEFA Europa League, formerly known as UEFA Cup). However, those proposals from FIFA did not convince the main European clubs. Thus, FIFA decided to change strategy with the objective of gaining control of the new competition. FIFA actually decided to support and authorise the tournament as long as it was organised under the auspices of UEFA and the participating clubs received authorisation from their national football associations. Moreover, FIFA requested the tournament's official name to be changed to European Champion Clubs’ Cup. 
The working group set up by L'Équipe and the participating clubs met for the second time in Madrid on 21 May 1955, which shows the importance of Real Madrid and Santiago Bernabéu for the project (Ball, 2012, p. 121). It was in that meeting when the clubs and L'Équipe accepted FIFA's suggestions. They also adopted the format, schedule and revenue distribution arrangements of the tournament, which was set up to start with 16 participating clubs (Relaño, 2005, p. 21). A few days later UEFA accepted to take charge of the organisation of the competition following the format and the regulations adopted in Madrid. The European Cup was ready to start with the beginning of the new 1955-56 season.

\section{European integration and the European Cup}

In a historical analysis, the creation of the European Cup could well be considered as another symptom of the emergence of discourses on the need of European integration in the aftermath of World War II. The Benelux was created in 1947, and four years later the Treaty of Paris, setting up the European Coal and Steel Community (ECSC) was signed. Those were the precursors of the European Economic Community and, later, the Single European Market. Thus, the issue of further European integration was clearly high up in the political and public agendas during the first years of the European Cup (Bahamonde, 2002, p. 238). It is plausible to suggest that the general political context might have favoured the quick success of the European Cup.

There were a few precursors of the European Cup, but those competitions were of a more regional character within the continent. The lack of a solid transport and communications infrastructure was too high a hurdle to organise a truly pan-European competition in the first half of the $20^{\text {th }}$ Century. However, competitions such as the Mitropa Cup or the Latin Cup, albeit more restricted in geographical scope, demonstrate the appetite for supranational club tournaments. The first edition of the Mitropa Cup was played in August 1927. It was a competition played by the best teams in Central Europe between August and November each year. The Latin Cup, on the other hand, was an 
initiative of the Spanish FA, bringing together the league champions of France, Italy, Portugal and Spain. The Latin Cup was played over a four year cycle, each summer in one of the four participating countries (Relaño, 2005, p. 23).

Thus, the foundation of the European Cup can be seen as yet another symptom of the need to close the wounds left by two devastating wars on the European continent. One should not lose sight, however, of the fact that the main objective of such a competition was to decide, on the football pitch, the supremacy of one country over the others. There is a twofold dynamic in the creation of the European Cup. On the one hand, there is an undeniable integrating effort to create a supranational football competition. On the other hand, national championships were maintained and clubs represented their own national FA when competing in the European Cup. The resilience of the nation-state in football terms is well portrayed in the well established one member-one vote decision making mechanism maintained by both FIFA and UEFA since their creation. With the benefit of hindsight, it is well plausible to argue that the favourable climate towards European integration could have influenced the decision to create the European Cup. However, our content analysis of the press reveals no mention at all to the political agenda of the time. The thematic analysis reveals a total lack of mention to the European integration process. A possible explanation to this finding is methodological. It is of course possible that our search, quite restricted and focused on discourse around Real Madrid and particular matches, has missed the wider picture. However, it is necessary to remind that the main focus of this research (and this chapter) is the discourse and the perception of Real Madrid's victories. This chapter contributes to wider research within the FREE Project on collective football memory. Thus, references to the European integration process would need deeper references to the socio-political context of the time and, naturally, a wider research effort that is outside the scope of this chapter. Finally, it is also necessary to point out that this chapter has focused on two countries (Spain and the United Kingdom) that were extremely peripheral to the European integration process in the late 1950s. The United Kingdom only joined the European Communities in 1973 and Spain even later, in 1986. Moreover, 
during the late 1950s Spain was politically isolated from the rest of Europe, as we argue in the following section.

Despite not finding any references to the European integration process in the press we have analysed, it is still possible to relate the creation of the European Cup to European integration. The creation of the European Cup can be seen as a group of clubs - with an advanced understanding of football for the time - that is willing to exploit the economic opportunities of the new competition. One should not forget that the distribution of income was one of the key decisions when setting up the competition. Thus, the founding clubs of the European Cup can be conceptualized as economic elite pulling together resources to create a bigger market for their product. This conceptualisation as economic elite of course brings forward some similarities with the concept of neofunctionalism, as first formulated by Haas (1968) and Lindberg (1963). In football one finds the elite of another economic sector that is favourable to economic integration. In this case of football, however, it is not possible to identify the fully fledged dynamic of neofunctionalism, whereby economic integration in a particular sector will spill over to other related sectors. Indeed, even if the concept of pro-integrationist economic elite, as defined by Haas, can be recognised in football, it is also undeniable that the final format of the competition is of an intergovernmental nature. Thus, in the creation of the European Cup it is possible to identify the two competing arguments in the literature around European integration. On the one hand, the clear support of supranational structures (UEFA, European Cup) and, on the other hand, the resilience of intergovernmental structures as each national FA is represented by one team in the new competition.

\section{Slowly overcoming Spain's international isolation}

One of the main characteristics of General Franco’s dictatorship in Spain was a complete international isolation. Initially it was the regime’s own choice, through a policy of autarchy and total disdain of the external relations (Juliá, 2005, p. 90). This policy of isolation was deeply 
entrenched in the regime's ideology. Franco's regime tried to shape itself as an effective fusion of the authentic Spanish traditional values (tradition, monarchy and Catholicism) with a new fascist ‘policy-making’ style under the direction of General Franco (Juliá, 2011, p. 530).

However, General Franco’s support of the Nazi-Fascist coalition during World War II suggests that he would have found very difficult to establish fruitful international relations even if he had tried. The United Nations rejected Spain’s membership application in June 1945 and France closed its border with Spain. On 12 December 1946, the United Nations General Assembly passed a declaration recommending to severe any diplomatic relations with Spain; a suggestion that was indeed followed by most countries except Argentina, Portugal, Ireland, Switzerland and the Vatican (Fusi, 2012, p. 231). Moreover, the United Kingdom maintained diplomatic and political pressure, demanding a transition towards a democratic monarchy in Spain (Di Febo and Juliá, 2005, p. 64). After the end of World War II, Franco's regime refused to receive American foreign aid because of its rejection of liberalism. Five years later, when France, Germany, England and Italy had already almost completely rebuilt their economies, it did receive this aid (García de Cortázar and González, 1996, p. 664). The initial isolation could not be maintained for long, not only because of the needs of the population, but also because numerous commercial and business sectors started to oppose the system of autocracy and interventionism. The regime responded to the external pressures of the summer of 1945 by accenting its Catholic and anti-communist content and reducing the fascist symbols of the uniforms and salutes (Di Febo and Juliá, 2005, p. 62).

In 1947 the idea began to take root that the policy of international isolation had strengthened Franco in Spain, and that it had not served to facilitate national concordance. On the other hand, the United States took note of the geo-strategic importance of Spain and was impressed to observe Franco’s virulent anti-communism. The Cold War increased Franco's value in the eyes of the United States. As a result of this change in perspective, in January of 1948 the United States approved a proposal of the National Security Council to normalise relations with Spain. In February of that same year, France reopened its borders, and shortly after that, Great Britain, Italy and France signed 
commercial agreements with Spain. In August 1950 Spain was awarded the first of a long series of loans, and only three months later pressure from the United States caused the United Nations to lift the boycott it had imposed after the Second World War, when Spain was considered 'the last holdout of fascism' (Shaw, 1987, p. 162). In 1951 there was a remodelling of the ministerial cabinet which gave the more moderate wing of the regime more power, and there began to be changes in the commercial ambit.

In 1953, Spain signed an agreement that allowed the USA to have military bases and installations on Spanish soil. In exchange, the United States granted Spain economic aid amounting to approximately \$ 1 billion. That same year, a concordat was signed with the Vatican, and two years later Spain entered the United Nations. The international isolation had ended, and the regime began a new phase (Di Febo and Juliá, 2005, p. 65). It is true that in various European countries and in the Eastern bloc there continued to be firm opposition to General Franco’s regime, but the image of a backwards country under the repression of a military dictatorship gave way to that of a touristic destination with sun and beaches, flamenco, bullfights and, of course, exciting football games. Starting in 1955, Spain became a nation recognised by the international community, although certainly without democratic legitimacy (Fusi, 2012, p. 232).

When in the year 1957 the European Communities started to put into effect its model of European integration, the most conservative ministers in the government reacted with their characteristic disdain and public negativity towards Europe. However, the technocrats, who had come to form part of the government paid close attention to the process and to the opportunities that this integration would offer the Spanish economy. Europeanism entered the Spanish public opinion, and at the end of the 1950s, 'Spaniards had the certainty that their destiny, in the short or long term, was none other than Europe’ (García de Cortázar and González, 1996, p. 616). This conviction was installed permanently in the elites and, progressively, would extend among the middle classes and more active groups in urban areas. This ‘support for Europe' could also be seen in the enthusiasm of Real Madrid for the European Cup, which we turn to in the following section. 


\section{Key findings: Real Madrid and the emergence of a European football public space?}

The previous section has provided a solid historical and political context to understand, on the one hand, the role of Real Madrid for the European Cup's early success and, on the other hand, the importance of the tournament and the club in Spain's geopolitical development after World War II. It is now time to turn to the presentation of the empirical research. In this section we structure our analysis along thematic areas, consistent with our review of the written sources. This is not quantitative content analysis, but it should be understood as a scoping review and a discussion of the main relevant themes. For the sake of clarity we have divided our finding into three main themes. First, we look at Real Madrid's enthusiasm for the creation of the European Cup. The second theme relates to the reaction of the Spanish political authorities to Real Madrid's success. Finally, we have identified a third theme that relates to the on-field heroes themselves. Here we have found a clear admiration both in Spain and Britain for the skill and prowess of Alfredo Di Stéfano and Ferenc Puskas.

\section{Real Madrid's enthusiasm for the creation of the European Cup}

The directors of Real Madrid were no strangers to this process of cultural change in the Spanish public opinion and when the French newspaper L'Équipe launched the proposal of a European Cup, the response of Real Madrid was quite enthusiastic. The president of the Spanish Football Federation, Juan Touzón, declared to a reporter from L'Équipe shortly after the idea of the European Cup was launched: 'I like this project a lot, and so does my friend Santiago Bernabéu, president of Real Madrid, with whom I am having conversations on the topic. Spain is willing to receive teams from all the European countries in its stadiums with a capacity for 100,000 spectators, including those behind the iron curtain’ (quoted by Bahamonde, 2002, p. 239). But why? What were the reasons for Real Madrid's interest in the creation of a European Cup? What did the 
leadership see in this new European tournament that motivated them to participate so enthusiastically from the beginning?

When $L$ 'Équipe made the proposal for the European Cup at the end of 1954, Real Madrid was a team with a pretty mediocre sports record. With the exception of the victory in the 1953-54 league, they had spent twenty years without winning any competition, and they had won fewer leagues than FC Barcelona (six), Athletic Club Bilbao (five), Atlético de Madrid (four) and Valencia CF (three) (Prados de Plaza, 2001, p. 162). However, two events produced changes in the club: the arrival of Santiago Bernabéu as chairman in 1944 and the signing of Argentinian forward Alfredo Di Stéfano in 1953.

Santiago Bernabéu was a player and coach for Real Madrid before becoming president. He had a law degree and, just after becoming president of the club, he surrounded himself with a professional team that included Raimundo Saporta, a man coming from basketball with a reputation as a tough negotiator (Simón, 2012, p. 113). He played a key role in signing up Alfredo Di Stéfano, as well as on many other occasions. Saporta was well-connected in high places, the bank and the news media (Prados de Plaza, 2001, p. 156; Ball, 2010, p. 112).

After being in charge of the club for a year, Bernabéu decided to finance the complete reconstruction of the Chamartín Stadium. The reconstruction was finished in December 1947, and re-baptised with his own name in 1955 (Ball, 2010, p. 112). Therefore, for Real Madrid the European Cup was a project that would allow it to consolidate economic development in the form of the construction of a new stadium for 120,000 people, a capacity that at the time doubled that of the stadium of Atlético de Madrid and tripled that of FC Barcelona (Bahamonde, 2002, p. 243). Later events showed that the new stadium would become the club's totem. The seventeen games that Real Madrid played there in the first five editions of the European Cup all ended with a 'white' victory and with a minimum difference of two goals (except on one occasion). Moreover, the visiting clubs and the press that accompanied them were always overwhelmed by the proportions of 
a stadium that was so monumental, full, and dedicated to supporting its team (Bahamonde, 2002, p. 251). But Real Madrid's enthusiasm for the European Cup went beyond merely taking advantage of the new stadium. Real Madrid realised that the development of professional football satisfied economic and social needs that surpassed the possibilities generated by national tournaments. The white club had already applied this type of reasoning between 1926 and 1928 when Spain debated the creation of a national football league (Bahamonde, 2002, p. 242). At that time, it argued that the recent adoption of professionalism required a reform of the geographical framework of the competitions, as its regional character limited the number of possible games to finance the increase in expenses stemming from professionalisation. This increase in expenses could only be compensated by going from the regional to the national sphere (Llopis-Goig, 2009, p. 49). Having uncovered the reasons behind Real Madrid’s support of the European Cup, the section moves now to analyse the reaction of General Franco's regime to the club’s victories in the new European competition.

\section{The Spanish authorities and the European hegemony of Real Madrid}

The consecutive victories of Real Madrid in the first five editions of the European Cup contributed decisively to the improvement of the image of Franco's Spain abroad, as pointed out by numerous academics and researchers of the period (Fernández, 1990; Shaw, 1987; Prados de Plaza, 2001; González Aja, 2002; Bahamonde, 2002; Ball, 2010; González Calleja, 2010; Viuda-Serrano, 2013). And this was true not only due to the five convincing European Cups victories, but also to the results achieved against their rivals, their playing style, and their capacity to overcome adverse scoreboards.

The government quickly detected that Real Madrid's victories could be useful to them, on the one hand, to increase the internal cohesion of a society that was going through great economic difficulties and, on the other, to project to the exterior the image of a nation of winners, worthy of being invited to return to the international scene (Ball, 2012, p. 117). After the signing of the 
agreement with the United States in 1953, the authorities quickly discerned the possibility of beginning to overcome the commercial and diplomatic isolation they had suffered, and the success of Real Madrid meant a magnificent materialisation of this tendency.

The Spanish football national team finished fourth in the 1950 World Cup in Brazil, but it did not get any further. They did not even qualify for the World Cup finals in 1954 and 1958, as they were embarrassingly eliminated by Turkey and Switzerland, respectively. The image of the Spanish national team languished in the 1950s, at the very same time that Real Madrid reached its hegemonic position in European football.

This contrast between the contributions of the Spanish national team and those of Real Madrid became evident in 1960. The Spanish Football Association - at the insistence of the Council of Ministers - withdrew the national team from the quarter finals of the inaugural edition of the European Cup of Nations in 1960, in order to avoid playing against the Soviet Union. This would occur only a few days after Real Madrid obtained its fifth European Cup in Glasgow and reaffirmed its leadership in Europe. The English press was very critical of the decision made by the regime: 'This act of arbitrariness and coercion with regard to the Spanish football players who wanted to play against the Soviet Union shows that Spain's fascist dictator trounces on the principles of the international Olympic movement and the international sports federations’ (The Times, 26 May 1960).

The regime was completely aware of the importance of Real Madrid’s triumphs in those years, and this is demonstrated in the words of José Solís, Secretary Minister of the Movement, to the players in October 1959. During a dinner the club offered to its players and the members of the Luxembourg Jeuneusse d’Esch club - after a resounding Real Madrid victory of 5-0 - Solís stood up and said:

'You have done more than many embassies strewn across God's country. People who hated us, now understand us, thanks to you, because you broke down a lot of walls... Your victories are a true source of pride for all Spaniards, inside and outside of our 
country. When you go to your dressing rooms at the end of each match, know that all the Spanish people are with you and proudly accompany you in your victories, which set the Spanish standard so high’ (Bulletin of Real Madrid CF, number 112, 1959; quoted by Shaw, 1987, p. 18).

The Foreign Minister of the Government of Spain, Fernando María Castiella, went even further, by considering the club as a true ambassador of the country: 'Real Madrid has, moreover, a sportsmanlike style and knows how to take the name of Spain throughout the world with the maximum decorum. Its players behave like true ambassadors by contributing with their actions to the prestige of our country' (ABC, 12 December 1968). It is not surprising that a few years later the journalist Francisco Cerecedo would write, in a somewhat ironic tone, the following words: 'Without doubt, the three decisive events of the period from 1950 to 1960 were the signing of the Concordat with the Vatican, the pact with the United States, and the five European Cups. It can be said that Pius XI, Eisenhower and Bernabéu led Spain to become a full-fledged member of the international community’ (Cerecedo, 1974).

\section{Di Stéfano and Puskas: the heroes of the five European Cups}

Of the 36 players that took part in the matches of the first five European Cups, eight were foreigners: Di Stéfano, Rial, Kopa, Santamaría, Domínguez, Puskas, Canario and Didí. The team had an indisputable leader, Alfredo Di Stéfano, the great catalyst of Real Madrid in the second half of the 1950s who played 35 of the 37 matches of the five first European Cups. Di Stéfano joined the club in 1953. From the outset, he showed exceptional qualities for football. In addition to his style, ability and technical skill, he had an extraordinary physical preparation that was manifested in both speed and his capacity for resistance. But what made him unique and a player especially admired by his fans was the way he combined his tactical intelligence with an exceptional team spirit. The team revolved around his tactical ideas at the same time that he gave his all to his teammates and took charge of the playing field. Di Stéfano set the rhythm of the match and elaborated the strategy to 
follow in each of its phases. This was added to terrific effectiveness marking goals: he was the maximum goal maker of the team in the European Cup, marking 36 of the 112 goals made by the team (Bahamonde, 2002, p. 252). In 1957 and 1959, the magazine France Football awarded him the Golden Ball for the best European player of the year.

Another important addition was Puskas, who came to Real Madrid in 1958. His arrival formed part of a broader emigration of Hungarian players motivated both by political reasons and by economic aspirations. The majority of them had fled from Hungary after the failure of the uprising of 1956, and they had a huge reputation as footballers. The Hungarian uprising of 1956 was immensely popular in Spain, due to its nature as a nationalist, anti-communist and perceived Catholic insurrection. Initially, the Spanish clubs faced numerous obstacles from FIFA to sign up these footballers, as a consequence of the negatives of the Hungarian Federation, although they were later given permission. They were all granted Spanish nationality under the label of 'political refugees', and so some of them were even able to play with the Spanish national team itself (Shaw, 1987, p. 145).

Puskas had been the captain of the Hungarian national team that defeated England in 1953 and that unexpectedly lost the World Cup final in 1954. He was also the skipper of Honved Budapest. In November 1956, Honved left for Spain to play a match against the Athletic de Bilbao, a rival they had been paired with in the round-of-sixteen draw of the second edition of the European Cup (Relaño, 2005, p. 38). The plans were to play matches in Western Europe in the hope of being hired by European clubs. Honved players knew about the success of Ladislao Kubala, another great Hungarian player who was hired by FC Barcelona in 1950. In a way, Kubala’s arrival into Spain as apolitical refugee and his success for FC Barcelona was the model that Puskas and his Honved teammates were trying to emulate in an attempt to scape their native Hungary. Puskas and the other Honved players knew that the Spanish authorities were not reluctant to grant them political asylum, taking into account the regime’s need to express its anti-communism in order to achieve a greater perception of liberality and legitimacy at an international level. 
After losing to Athletic de Bilbao, Honved players decided to start a tour through Europe. UEFA imposed a ban on Puskas for refusing to play with the new Honved of Budapest. When Real Madrid expressed interest in him, he was in Italy almost retired from football. The negotiation skills (or the money) of Real Madrid, however, managed to convince UEFA to lift the ban on Puskas. He played a total of 12 matches in the fourth and fifth editions of the European Cup, in which he scored a total of fourteen goals. Puskas made an outstanding tandem with Alfredo Di Stéfano in Real Madrid until 1964, and he became an even more important anti-communist symbol than Kubala. After obtaining Spanish nationality, he played with the Spanish national team in the 1962 World Cup in Chile. Before the referendum on the Organic State Law of 1966, an important piece of legislation for the regime, Puskas appeared on television together with Franco, advising the country to vote for this legislation.

\section{Conclusion}

This chapter has tried to examine the significance and contribution of Real Madrid's victories in the first five editions of the European Cup in setting up a European football space.

The first conclusion that can be drawn is that the analysis made by the British and Spanish press of the time did not make it possible to see a relationship of clear causality between the emergence of what could be considered the embryo of the current European Union and the appearance of the European Cup of clubs. However, it should be kept in mind that this circumstance is completely related to the peculiarities of the countries where this press was publishing. British society remained distanced from the new competition, and its press initially did not give it much importance. In the Spanish case, the sport press paid close attention, but its analyses did not go beyond what was strictly related to sports. On the other hand, the general press was quite conditioned by the moral imposed by the regime, and if they went beyond sport aspects, it was to patriotically praise the triumphs of Real Madrid. The analysis has shown, however, that there was a cultural climate 
favourable to the creation of the European Cup - whose antecedents were in the Latin Cup, the Mitropa cup -, which materialised at the moment when the objective conditions were ready (technology, means of transport, overcoming the pains of war, beginning of television). The second conclusion is that the overwhelming superiority of Real Madrid with its five consecutive victories facilitated the articulation of a European football space. Its playing style and stunning results placed Real Madrid in the centre of the European football scene and made it the reference for modernity and sports excellence, capturing the attention of the rest of the European clubs. In a significant way, a public opinion space emerged that, thanks to the recognition of the superiority of Real Madrid, transcended national borders (see also the contribution of Geoff Hare to this volume). At a time when the embryo of the current European Union was not more than a mere free trade agreement between a few countries, a club from the southern part of the continent, and specifically, from isolated Spain, reached the hegemony of the European competition. In this achievement, the contribution of Di Stéfano was essential, but also that of Puskas, a footballer from Eastern Europe who in this way became a part of the historical record of European football. The presence of Eastern European footballers in Spain contributed decisively to the configuration of a transnational football space in the European setting. Real Madrid became internationalised with the presence of Puskas, and it strengthened its European prestige at a sports level and as a club. Spain acquired a pretext to rehabilitate its image during the Cold War, showing its liberal nature by taking in and granting nationality to refugees from communist countries. Thus, a public opinion space on a European scale started to emerge at a time when the political circumstances still did not allow an institutional structure to be observed.

The victories of Real Madrid, then, clearly contributed to the structure of the European football space by converging Southern and Eastern Europe in a scenario created from Central Europe. For all of these reasons, perhaps it would be necessary to revise the initial hypothesis and wonder whether the European football space, with its popular support and social diffusion, contributed more 
than other agencies or institutions to the development of the 'European emotional wiring', to a degree unimagined by the promoters of the European Union and unknown to its current leaders.

\section{Bibliography}

Bahamonde, A. (2002) El Real Madrid en la Historia de España (Madrid: Editorial Taurus). Ball, P. (2012) Tormenta blanca. La historia del Real Madrid 1902-2012 (Madrid: T\&B Editores). Ball, P. (2010) Morbo. La historia del fútbol español (Madrid: T\&B Editores).

Cerecedo, F. (1974) ‘Sociología insolente del fútbol español’. Posible, nº 13, Madrid, 15 December 1974.

Di Febo, G. and Juliá, S. (2005) El franquismo (Barcelona: Paidós).

Fernández, C. (1990) El fútbol durante la guerra civil y el franquismo (Madrid: San Martín). Fusi, J. P. (2012) Historia mínima de España (Madrid: Turner Libros).

García de Cortázar, F. and González Vesga, J. M. (1996) Breve Historia de España (II) (Madrid: Alianza Editorial).

González Aja, T. (2002) ‘La política deportiva en España durante la República y el Franquismo’, in González Aja, T. (ed.): Sport y autoritarismos. La utilización del deporte por el comunismo y el fascismo (Madrid: Alianza Editorial), pp. 169-202.

González Calleja, E. (2010) ‘El Real Madrid ¿equipo del régimen? Fútbol y política durante el Franquismo', in Esporte e Sociedade, Vol. 5, Issue 14, pp. 1-19.

Greenhalgh, P. (1988) Ephemeral vistas: the expositions universelles, great exhibitions, and world's fairs, 1851-1939 (Manchester: Manchester University Press).

Haas, E. (1968) The Uniting of Europe: Political, Social and Economic Forces 1950-1957, $2^{\text {nd }}$ edition (Stanford, California: Stanford University Press).

Juliá, S. (2005) 'La sociedad’, in García Delgado, J. L. (coord.) Fusi, J. P., Juliá, S., Malefakis, E. and Payne, S. G. Franquismo. El juicio de la historia (Madrid: Ediciones Temas de Hoy), pp. 69143. 
Juliá, S. (2011) ‘Edad Contemporánea’, in Valdeón, J., Pérez, J. and Juliá, S. (eds): Historia de España (Madrid: Espasa Libros), pp. 365-578.

Lindberg, L. N. (1963) The Political Dynamics of European Economic Integration (Stanford, California: Stanford University Press).

Luque, X. G. and Luna, J. (2004) ‘Notario en las trincheras del deporte’, in La Vanguardia, 30 May 2004, p. 63.

Llopis-Goig, R. (2009) ‘Sociedad plural, fútbol postnacional. Evolución y transfor-maciones socioculturales del fútbol español’, in Llopis-Goig, R. (ed.) Fútbol Postnacional. Transformaciones sociales y culturales del deporte global en Europa y América latina (Barcelona: Editorial Anthropos), pp. 47-62.

Prados de Plaza, L. (2001) Real Madrid Centenario (Madrid: Silex Ediciones).

Relaño, A. (2005) 50 años de la Copa de Europa. De la prehistoria y el penta-campeonato del Real Madrid, Volumen I. (Madrid: AS).

Shaw, D. (1987) Fútbol y franquismo (Madrid: Alianza Editorial).

Simón, J. A. (2012) ‘Jugando contra el enemigo. Raimundo Saporta y el primer viaje del equipo de baloncesto del Real Madrid CF a la Unión Soviética’, in Revista Internacional de Ciencias del Deporte, Vol. 28, pp. 109-126.

Viuda-Serrano, A. (2013) ‘Santiago Bernabéu y el Real Madrid. Un análisis histórico del mito del fútbol. Política y deporte en la España franquista’, in Agon International Journal of Sport Sciences, Vol. 3, Issue 1, pp. 33-47. 